\title{
HUBUNGAN ANTARA PEMBERIAN ASI EKSKLUSIF DENGAN PERKEMBANGAN ANAK BERDASARKAN KUISIONER PRA- SKRINING PERKEMBANGAN (KPSP) DI RUMAH SAKIT TARAKAN JAKARTA
}

\author{
Melanie Rakhmi Mantu' ${ }^{1}$, Andrey Setiawan ${ }^{2}$, Novi Handayani ${ }^{3}$ \\ ${ }^{1}$ Fakultas Kedokteran Universitas Tarumanagara \\ Surel: melaniemantu@yahoo.com \\ ${ }^{2}$ Departemen Ilmu Kesehatan Anak Rumah Sakit Umum Daerah Tarakan \\ ${ }^{3}$ Departemen Ilmu Kesehatan Anak Rumah Sakit Umum Daerah Tarakan
}

\begin{abstract}
ABSTRAK
Menyusui eksklusif selama 6 bulan atau lebih telah direkomendasikan oleh banyak organisasi kesehatan dunia. Menyusui eksklusif adalah fondasi bagi perkembangan dan kesehatan anak yang berkelanjutan karena diyakini bahwa ASI dapat menghasilkan perkembangan fisik, kognitif, dan emosional yang maksimal. Tujuan Untuk menilai korelasi pemberian ASI eksklusif dengan perkembangan anak berdasarkan KPSP dan menilai faktor-faktor yang mempengaruhi pelaksanaan pemberian ASI eksklusif pada pasien rawat jalan di Rumah Sakit Tarakan. Metode: Penelitian cross-sectional yang melibatkan 107 pasien rawat jalan di Rumah Sakit Tarakan yang berusia 0-60 bulan yang diperoleh dengan menggunakan consecutive sampling. Data dikumpulkan dengan wawancara menggunakan kuesioner yang valid dan KPSP berdasarkan usia anak dari Februari hingga April, 2017. Analisis data yang digunakan adalah uji-t tidak berpasangan, chi square dan Mann-Whitney dengan signifikansi 5\% menggunakan SPSS v23. Dari 107 anak, 43 (40,2\%) menerapkan pemberian ASI eksklusif dan 88 (82,2\%) normal pada penyaringan. Ada perbedaan yang signifikan antara pendidikan ibu $(p=.043)$, etnis ibu $(p=.004)$, metode pengiriman $(p=.020)$, lokasi perawatan natal ante $(A N C)$ lokasi $(p=.040)$, inisiasi awal dari menyusui $(p=$ 0,017) dibandingkan dengan pelaksanaan pemberian ASI eksklusif dengan uji-T tidak berpasangan. Juga dapat disimpulkan bahwa usia anak dalam pemberian ASI eksklusif secara statistik tidak lebih tinggi secara signifikan daripada kelompok pemberian susu formula $(p=0,420)$. Tidak ada hubungan yang signifikan antara pemberian ASI eksklusif dan perkembangan anak berdasarkan KPSP $(p=0,481)$ Kesimpulan Tidak ada hubungan antara pemberian ASI eksklusif dan perkembangan anak berdasarkan KPSP dan pemberian ASI eksklusif dipengaruhi oleh pendidikan ibu dan etnis, metode pengiriman, lokasi ANC, inisiasi dini setelah lahir.
\end{abstract}

Kata Kunci : Menyusui, perkembangan anak, KPSP, pra-skrining.

\section{PENDAHULUAN}

Air Susu Ibu (ASI) eksklusif dapat diartikan sebagai suatu pelaksanaan dengan hanya memberikan air susu ibu kepada bayi dalam 6 bulan pertama kehidupan, termasuk untuk tidak memberikan makanan atau minuman lainnya (Department of Nutrition for Health and Development, 2014). Pemberian ASI eksklusif telah di rekomendasikan oleh banyak organisasi kesehatan dunia, termasuk American Academy of Pediatrics (AAP) dan World Health Organization (WHO) (Parks, Krebs, Michaelsen, Morton, 2016, 2009, 2015, 2011). Pemberian ASI secara umum dianjurkan untuk dilanjutkan dengan mengonsumsi makanan tambahan yang sesuai hingga usia 2 tahun, sesuai dengan keinginan ibu dan anaknya (Parks, Krebs, 2016, 2009). Pemberian ASI eksklusif adalah dasar keberlangsungan dan kesehatan anak karena ASI memberikan nutrisi yang penting dan tidak bisa digantikan untuk pertumbuhan dan perkembangan anak (Department of Nutrition for Health and Development, 2014).

Keuntungan pemberian susu manusia dibandingkan susu sapi adalah pengaruh yang signifikan terhadap pertumbuhan, perkembangan neuro-kognitif, serta pencegahan penyakit kardiovaskular, necrotizing enterocolitis (NEC), penyakit traktus gastrointestinal, penyakit traktus respiratorius, 
penyakit autoimun, penyakit infeksi, obesitas, dan masih banyak keuntungan lainnya. Selain hal yang telah disebutkan, menyusui juga merupakan sarana membangun hubungan (bonding) antara ibu dan anaknya serta memiliki keuntungan ekonomis (Eidelman, Schanier, 20120. Keuntungan ini dipengaruhi oleh sifat eksklusifitas dan durasi pemberiannya, sehingga promosi oleh tenaga kesehatan dalam pemberian ASI eksklusif memegang peran yang positif (Morton, Lawrence, 2011).

Menurut laporan WHO pada tahun 2015, secara global, yaitu 38\% bayi berusia $0-6$ bulan yang menjalani anjuran ASI eksklusif (World Health Organization, 2015). Sedangkan berdasarkan laporan Profil Kesehatan Dasar tahun 2015, secara nasional cakupan ASI Eksklusif adalah $55.7 \%$ yang telah memenuhi target Rencana Strategis Kementerian Kesehatan tahun 2015 yaitu 39\%. Provinsi Daerah Khusus Ibukota (DKI) Jakarta pada tahun 2015, cakupannya adalah $67.1 \%$, masih jauh tertinggal bila dibandingkan dengan Provinsi Nusa Tenggara Barat yang memiliki cakupan tertinggi secara nasional, yaitu 86.9\%. (Kementerian Kesehatan Republik Indonesia, 2015)

Masalah perkembangan anak seperti gangguan bahasa, perilaku dan lainnya belakangan ini menarik semakin banyak perhatian sehingga sekiranya dibutuhkan deteksi dini kejadian gangguan pada perkembangan anak. Banyak kuisioner yang sudah terstandardisasi untuk melakukan deteksi dini, salah satunya adalah prescreening developmental questionnaire (PDQ) yang diterjemahkan dan dimodifikasi menjadi Kuisioner Praskrining Perkembangan (KPSP), dimana menilai empat aspek perkembangan melalui pertanyaan-pertanyaan yaitu motorik kasar, motorik halus, bicara dan bahasa serta sosialisasi dan kemandirian (Artha, Dhamayanti, Simangunsong, 2014, 2006, 2012).

Berdasarkan hal tersebut diatas, maka tujuan penelitian ini adalah untuk mengetahui korelasi antara pemberian ASI Eksklusif dengan perkembangan anak yang dinilai berdasarkan KPSP dan juga menilai faktor-faktor yang mempengaruhi pelaksanaan ASI Ekslusif pada pasien rawat jalan di Departemen Ilmu Kesehatan Anak, Rumah Sakit Umum Daerah Tarakan, Jakarta.

\section{METODE PENELITIAN}

Penelitian ini adalah penelitian cross sectional yang melibatkan 107 pasien rawat jalan di Departemen Ilmu Kesehatan Anak, Rumah Sakit Umum Daerah Tarakan yang berusia 0-60 bulan. Subjek penelitian di pilih menggunakan metode consecutive sampling dimana pasien yang bersedia di periksa akan dijadikan subjek penelitian. Kemudian orang tua pasien akan ditanyakan oleh tenaga terlatih untuk kuisioner yang berisi data umum dan khusus yang sudah di validasi serta ditanyakan menggunakan KPSP sesuai dengan usianya. Bila didapatkan hasil dibawah 9 maka dianggap hasil perkembangannya memerlukan rujukan untuk mengintervensi masalah yang dihadapi, sedangkan bila mendapatkan angka 9 atau 10 maka dianggap perkembangan anak tersebut normal menurut usianya. Penelitian ini dilakuakn dari bulan Februari hingga April 2017. Analisis data menggunakan unpaired t-test, chi square dan Mann-Whitney dengan menggunakan program SPSS versi 23.

\section{HASIL DAN PEMBAHASAN}

Karakteristik subjek yang dinilai adalah jenis kelamin, faktor ibu dan ayah (usia, pekerjaan, pendidikan, dan suku bangsa), diagnosis anak, metode persalinan, berat badan lahir, jumlah anak, paparan rokok, status gizi ibu, pendapatan, riwayat pemberian ASI dan MPASI, riwayat frekuensi dan lokasi Ante Natal Care (ANC), dan Inisiasi Menyusui Dini (IMD) 
Tabel 1.Gambaran Umum Subjek Penelitian

\begin{tabular}{ccc}
\hline Karakteristik & $\begin{array}{c}\text { Jumlah } \\
\mathrm{n}=107\end{array}$ & $\begin{array}{c}\text { Persentasi } \\
\mathrm{n}=100 \%\end{array}$ \\
\hline Jenis Kelamin Anak & 59 & 55.1 \\
Laki-laki & 48 & 44.9 \\
Perempuan & & \\
Usia Ibu & 1 & 0.9 \\
$<=20$ tahun & 42 & 36.3 \\
21-29 tahun & 64 & 59.8 \\
>=30 tahun & & \\
Bekerja & 24 & 22.4 \\
IRT & 83 & 77.6 \\
Pekerjaan Ibu & & \\
Pendidikan Ibu & 23 & 21.5 \\
<SMA & 65 & 60.7 \\
SMA & 19 & 17.8 \\
>SMA & & \\
Ya & 43 & 40.2 \\
Tidak & 64 & 59.8 \\
\hline
\end{tabular}

Subjek penelitian terdiri dari 107 orang, dengan jumlah jenis kelamin anak laki-laki 50\% lebih banyak dibandingkan perempuan. Usia ibu yang berumur lebih dari 30 tahun sebanyak 64 orang $(59,8 \%), 1$ orang $(0,9 \%)$ kurang dari 20 tahun, dan sisanya berumur antara 21 sampai 29 tahun. Sebanyak 83 orang $(77,6 \%)$ merupakan ibu rumah tangga, dan sisanya adalah bekerja. Untuk tingkat pendidikan 65 orang $(60,7 \%)$ mempunyai pendidikan SMA, 19 orang $(17,8 \%)$ di atas SMA, dan sisanya adalah dibawah dari SMA. Hanya 43 orang $(40,2 \%)$ yang memberikan asi eksklusif, dan 64 orang $(59,8 \%)$ tidak memberikan asi eksklusif.

Tabel 2. Hubungan Pelaksanaan ASI Eksklusif dengan Perkembangan Anak dinilai dari Kuisioner Pra-Skrining Perkembangan (KPSP)

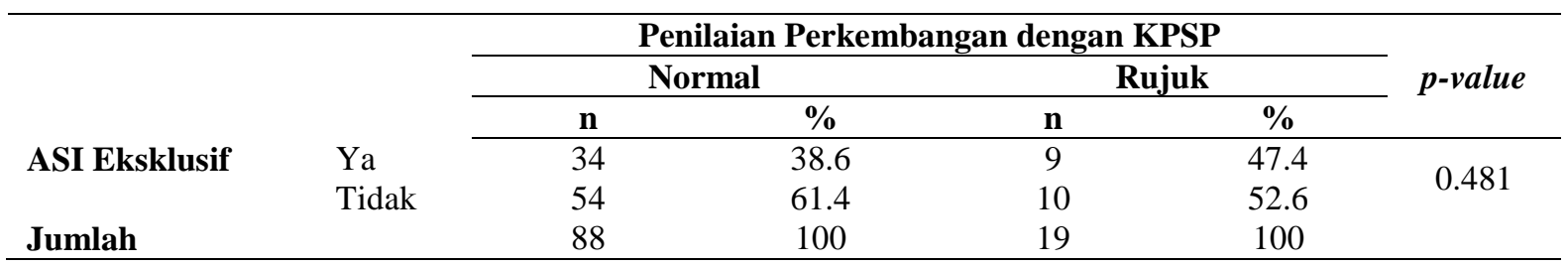

Berdasarkan hasil analisis statistik, tidak didapatkan hubungan antara ASI Eksklusif dengan perkembangan anak berdasarkan $\operatorname{KPSP}(p=0.481)$.

\section{KESIMPULAN DAN SARAN}

Bahwa dari hasil penelitian ini tidak didapatkan hubungan antara ASI Eksklusif dengan perkembangan anak yang dinilai menggunakan KPSP. Kemungkinan hal ini disebabkan karena perkembangan anak dinilai hanya dari KPSP saja. Dibutuhkan penilaian perkembangan yang menggunakan alat skrining lebih spesifik misalnya Denver II. 


\section{REFERENSI}

Artha NM, Sutomo R, Gamayanti IL. Kesepakatan hasil antara kuesioner pra skrining perkembangan, parent's evaluation of developmental status dan tes denver-II untuk skrining perkembangan anak balita. Sari Pediatri 2014; 16(4): 266-70.

Department of Nutrition for Health and Development. Global nutrition targets 2025: breastfeeding policy brief. Geneva: World Health Organization; 2014.

Dhamayanti M. Kuesioner praskrining perkembangan anak. Sari Pediatri 2006; 8(1): 9-11.

Eidelman AI, Schanier RJ. Policy statement: breastfeeding and the use of human milk. Pediatrics 2012; 129(3): e827.

Kementerian Kesehatan Republik Indonesia. Bab V: kesehatan keluarga. Dalam: Kementerian Kesehatan Republik Indonesia. Profil kesehatan indonesia 2015. Jakarta: Kementerian Kesehatan Republik Indonesia; 2015.h.144-6.

Krebs NF, Primak LE. Normal childhood nutrition \& its disorders. In: Hay WW, Levin MJ, Sondheimer JM, Deterding RR, editors. Current diagnosis \& treatment: pediatrics. 19th Edition. New York: The McGrawHill Medical; 2009.p.275-6.

Michaelsen KF. Breastfeeding. In: Koletzko B, Bhatia J, Bhutta ZA, Cooper P, Makrides M, Uauy $R$, et al, editors. Pediatric nutrition in practice. 2nd Edition. World Rev Nutr Diet. Basel: Karger; 2015.p.92-4.

Morton J, Lawrence RA. Breast-feeding. In: Rudolph CD, Rudolph AM, Lister G, First LR, Gershon AA, editors. Rudolph's pediatrics. 22nd Edition. New York: The McGrawHill Medical; 2011.p.320.

Parks EP, Shaikhkhalil A, Groleau V, Wendel D, Stallings VA. Feeding healthy infants, children and adolescents. In: Kliegman RM, Staton BF, St. Geme III JW, Schor NF, Behrman RE, editors. Nelson textbook of pediatrics. $20^{\text {th }}$ Edition. Philadelphia: Elsevier; 2016.p.286-7

Simangunsong SW, Machfudz S, Sitaresmi MN. Accuracy of the indonesian child development pre-screening questionnaire. Paediatr Indones 2012; 52(1): 6-8.

World Health Organization. World health statistics 2015. Luxembourg: World Health Organization; 2015.p. 110-1. 